\title{
Mensagem dos Coordenadores
}

Desde 2001, quando foi publicada a III Diretriz Brasileira sobre Dislipidemias e Prevenção da Aterosclerose pelo Departamento de Aterosclerose (DA) da SBC, muitos estudos clínicos dessa área tiveram seus resultados divulgados, causando importante impacto sobre o que determinava aquela diretriz. O DA, percebendo isso, trabalhou intensamente na produção de uma nova Diretriz, que englobasse todos esses novos conhecimentos. Os princípios maiores estabelecidos para o documento final foram os da simplicidade e praticidade, além da atualização. Assim, esta Diretriz traz o que há de mais atual na área das dislipidemias, de forma simples e prática, visando unicamente o médico que necessita das informações para nortear 0 atendimento de seus pacientes. Sabemos que o papel de uma Diretriz é o de estabelecer de forma clara os guias para a conduta na lida com pacientes, sem o que ela não tem sentido. Acreditamos que o instrumento está aqui e agora falta sua implementação na prática diária, para que seja atingida sua proposta. Para isso, é necessária a participação de cada um na sua divulgação e utilização rotineira e constante, fazendo desta Diretriz um Guia de Conduta que trará benefícios importantes para nossos pacientes.

Bom trabalho a todos!

Os Coordenadores. 